\title{
Characteristics of Cell Walls from Morphological Variants of Escherichia coli
}

\author{
By G. WEINBAUM \\ Research Laboratories, Department of Biochemistry, Albert Einstein \\ Medical Centre, Philadelphia, Pennsylvania, U.S.A.
}

(Received 12 July 1965)

\begin{abstract}
SUMMARY
Two strains (E-26 and B) of Escherichia coli were examined for their growth response in a medium containing $0.75 \%(\mathrm{w} / \mathrm{v}) \mathrm{NaCl}, 1 \%(\mathrm{w} / \mathrm{v})$ L-lysine hydrochloride, $2 \%(\mathrm{w} / \mathrm{v})$ glucose, $2 \cdot 4 \%(\mathrm{w} / \mathrm{v})$ nutrient broth, and $5 \%(w / v)$ casein hydrolysate. Strain E-26 grew as a rod which was slightly larger than when it was grown in a defined medium. Strain B grew as a filamentous and branched form; while in defined medium it grew as a rod of normal dimensions. Cell walls were isolated from both strains. Chemical analysis showed that the filamentous and branched forms had one-third the amount of hexosamine and one-fifth the amount of reducing sugar as compared with the morphologically normal form. The abnormal cell walls were more susceptible to trypsin action, more resistant to lysozyme action and more completely disaggregated by sodium dodecyl sulphate than the walls from the morphologically normal organisms.
\end{abstract}

\section{INTRODUCTION}

Many organisms exhibit morphological variation under a variety of conditions. It has been suggested (Hughes, 1956) that there are three main classes of agents which can cause aberrant long forms to appear in culture: (1) certain poisons, including antibiotics, (2) starvation, and (3) physical traumata. Mycobacterium acapulcensis grows as filamentous and globular forms in the presence of D-cycloserine (Mora \& Bojalil, 1965). Hughes (1956) has shown that low concentrations of penicillin can cause long forms of Proteus vulgaris to predominate in the culture. Other bacteriostatic agents such as 6-diazo-5-oxo-L-norleucine (Coggin \& Martin, 1965) or penicillin (Bartmann \& Höpken, 1956) can induce aberrant forms in Escherichia coli.

Holden \& Holman (1957) have shown by omitting pyridoxamine from cultures of Lactobacillus arabinosus that removal of an essential nutrient from the medium can cause aberrant forms. It was also reported that $L$. delbrueckii elongated abnormally when vitamin $B_{12}$ was eliminated from the medium (Kitahara \& Kusaka, 1959).

Anaerobiosis can cause 'thread' formation in Escherichia coli (Hughes, 1953), and ZoBell \& Cobet (1964) demonstrated that increased hydrostatic pressure (200$500 \mathrm{~atm}$.) caused filament formation in three strains of the same organism. Adler \& Hardigree (1964) showed that another physical trauma, exposure to ultraviolet radiation, caused non-septate filaments in $E$. coli $\mathrm{K}-12$. A culture of $E$. coli resistant to gamma-irradiation was isolated, and a most striking change was observed in its gross morphology (Pontefract \& Thatcher, 1965). There developed, as a permanent 
feature of the culture, long filamentous organisms with formation of vesicles or 'buds' from the sides or ends. It was suggested that these swellings were due to physical weaknesses in the cell wall, or that these 'buds' were abortive attempts at forming daughter organisms tangential to the parent.

Most investigators make use of some bacteriostatic agent to induce morphological variation. Recently, we reported a series of experiments which indicated that Escherichia coli в could be induced to form filamentous and branched forms in a medium devoid of any known bacteriostatic agent (Weinbaum, 1965). The results of these experiments can be briefly summarized as follows: (1) Three strains of E. coli (E-26, K-12, and B) were morphologically similar when grown in a minimal salts + glucose medium. However, when the three strains were grown in a medium containing $0.75 \%(\mathrm{w} / \mathrm{v}) \mathrm{NaCl}, 1 \%(\mathrm{w} / \mathrm{v})$ L-lysine hydrochloride, $2 \%(\mathrm{w} / \mathrm{v})$ glucose, $\mathbf{2} \cdot \mathbf{4} \%$ (w/v) nutrient broth, and $5 \%$ (w/v) Hycase (Sheffield Chemical Co., Norwich, N.Y.) they each showed a different morphological response. Strain E-26 retained its appearance as a normal short rod; strain $\mathrm{K}-12$ appeared much larger with many organisms appearing branched or triangular shaped. Strain B showed greater morphological variation; most organisms were filamentous and much wider than strain B grown in defined medium. Many of the organisms were also branched, and some were amorphous or spheroplast like. (2) The morphological variants of strain B could be continually propagated as filaments and branched forms by repeated serial subculturing in the Hycase-containing medium. However, within $5 \mathrm{hr}$ after the abnormal form of strain $\mathrm{B}$ was diluted $1 / 100$ into $1 \%(\mathrm{w} / \mathrm{v})$ nutrient broth, the majority of the organisms developed a normal short rod appearance. Therefore, the change in structure of strain $\mathrm{B}$ was environment-dependent, and was readily reversible as soon as the environment was changed. (3) It is known that magnesium deficiency causes filamentous growth in $\boldsymbol{E}$. coli (Brock, 1962), consequently the Hycase-containing medium was supplemented with $\mathrm{Mg}^{2+}, \mathrm{Ca}^{2+}$ and/or $\mathrm{PO}_{4}{ }^{3-}$. However, these additions had no effect on strain в filament formation. Other modifications of the medium showed that filament formation was induced by the casein hydrolysate (either Hycase or enzymically hydrolysed casein) and both L-lysine and nutrient broth were required to induce branching.

It was of interest, therefore, to examine the chemical composition of isolated cell walls of normal and aberrant forms of Escherichia coli for compositional differences to note whether the aberrant forms were due to aberrant wall synthesis, as opposed to inhibition of cell division by unknown mechanisms. Part of these results have been reported in preliminary form (Weinbaum \& Fischman, 1965).

\section{METHODS}

Organisms. Two strains of wild-type Escherichia coli were used in this study. Strains B and E-26 were generously supplied by Dr M. F. Mallette, Department of Biochemistry, Pennsylvania State University, and Dr H. C. Reeves, Department of Biochemistry, Albert Einstein Medical Centre, respectively. The cultures were maintained on slants of trypticase soy agar and subcultured weekly. Stock cultures were stored at $4^{\circ}$.

Conditions for growth and harvest. Cultures were loop inoculated from slants into $20 \mathrm{ml}$. of a minimal salts-glucose defined medium containing $0 \cdot 4 \%(\mathrm{w} / \mathrm{v})$ 
glucose, $\quad 0.05 \%(\mathrm{w} / \mathrm{v}) \mathrm{NaCl}, \quad 0.041 \%(\mathrm{w} / \mathrm{v}) \quad \mathrm{MgSO}_{4} .7 \mathrm{H}_{2} \mathrm{O}, \quad 0.1 \%(\mathrm{w} / \mathrm{v}) \quad \mathrm{NH}_{4} \mathrm{Cl}$, $0.6 \%$ (w/v) $\mathrm{Na}_{2} \mathrm{HPO}_{4}$ and $0.3 \%$ (w/v) $\mathrm{KH}_{2} \mathrm{PO}_{4}$ (Weinbaum \& Mallette, 1959) in a $125 \mathrm{ml}$. flask and shaken vigorously at $36^{\circ}$ overnight. A 1/400 dilution of this culture was made into inducing (Hycase) medium containing $0.75 \%(\mathrm{w} / \mathrm{v}) \mathrm{NaCl}$, $1 \%(w / v)$ L-lysine hydrochloride, $2 \%(w / v)$ glucose, $2 \cdot 4 \%(w / v)$ nutrient broth (Difco), and $5 \%(\mathrm{w} / \mathrm{v})$ casein hydrolysate (Weinbaum, 1965) and the organisms were again allowed to grow aerobically at $36^{\circ}$. Within $6 \mathrm{hr}$ the morphological variants of strain $B$ appeared, and the culture continued to grow for at least $16 \mathrm{hr}$. The organisms were harvested by centrifugation.

Isolation of cell walls. Cell walls from strains E-26 and B were isolated by vigorous shaking with glass beads according to the method of Shockman, Kolb \& Toennies (1957). Packed bacterial paste was suspended to a concentration of $10 \%(w / v)$ in either water or $0.4 \%(\mathrm{w} / \mathrm{v})$ sodium dodecyl sulphate (SDS) and 10 times the bacterial wet weight of glass beads (HD-E, $0.2 \mathrm{~mm}$., Prismo Potters, Huntingdon, Pa.) was added. The shaker head on the International centrifuge was operated at $-10^{\circ}$ and $1900 \mathrm{rev} . / \mathrm{min}$. and complete breakage was obtained after four 5 -min. runs. The cell walls were isolated by differential centrifugation and were washed 8-10 times with glass-distilled water. The SDS was initially used to inhibit any lytic enzymes (Weidel, Frank \& Leutgeb, 1963) but, since similar results were obtained by breakage in water, the SDS was usually omitted.

Enzyme treatment of cell walls. Lysozyme treatment of purified cell walls was performed according to the method of Repaske (1958) using $50 \mu \mathrm{g} . / \mathrm{ml}$. lyzozyme and $1 \times 10^{-3} \mathrm{M}$-EDTA. Changes in turbidity were measured using a Cary Model 14 recording spectrophotometer at $570 \mathrm{~m} \mu$ (Hirs, 1955). Trypsin treatment of purified cell walls was performed with $0.005 \%(\mathrm{w} / \mathrm{v})$ trypsin previously stabilized with $1 \times 10^{-3}{\mathrm{M}-\mathrm{Ca}^{2+}}^{2}$ (Bailey, 1962). Changes in turbidity were determined at $570 \mathrm{~m} \mu$.

Analytical methods. The purified cell walls were disaggregated with various concentrations of sodium dodecyl sulphate ( $\mathrm{pH} \mathrm{7.0)}$ (Shafa \& Salton, 1960) and the percentage decrease in turbidity at $570 \mathrm{~m} \mu$ recorded after a $10 \mathrm{~min}$. treatment with the detergent. Quantitative determination of cell-wall yields was accomplished by drying samples of cell-wall suspensions to constant weight using an infra-red heat lamp, and weighing on tared planchets. Each determination was prepared in triplicate. Total reducing sugar content was measured by the anthrone procedure of Scott \& Melvin (1953) with glucose as the standard. Hexosamines were determined by two procedures, the indole- $\mathrm{HCl}$ procedure of Dische $\&$ Borenfreund (1950) and the Elson-Morgan procedure (Winzler, 1955) using glucosamine as the standard. Two procedures were used since certain hydrolysis products react with one but not the other technique (Dische, 1955). Protein was determined by the method of Lowry, Rosebrough, Farr \& Randall (1951) with a standard curve obtained for human serum albumin. All results given are averages of at least three determinations. The reduced NAD oxidase activity of purified cell walls or dialysed supernatants was assayed at $\mathrm{pH} 6.8(0.05 \mathrm{M}$-phosphate buffer) by measuring the decrease in extinction at $340 \mathrm{~m} \mu$ with a recording spectrophotometer. The initial slope was used to give a measure of reaction rate. 


\section{RESULTS}

\section{Modification of inducing medium}

During an earlier investigation of the induction of aberrant cell formation in Escherichia coli B (Weinbaum, 1965), it was found that acid or enzymically hydrolysed casein caused filament formation when present at concentrations above $3 \%(w / v)$. Modification of the inducing medium by substituting other protein extracts or hydrolysates gave variable results. The aberrant organisms seen in Pl. 1, figs. 1-3 were induced to form filamentous and branched forms in medium in which Hycase was replaced by the same concentration of casitone (Difco, a vitaminfree peptone) or yeast extract (Difco). Substitution by Bacto-peptone (Difco), trypticase or polypeptone (both Baltimore Biological Laboratories) gave poorer induction of abnormal forms. It appeared, then, that certain protein extracts were more effective in causing $E$. coli B to grow as morphologically bizarre forms. E. coli $\mathrm{E}-26$, when grown in any of the inducing media described above, showed no propensity to form aberrant types, as can be seen in Pl. 1, fig. 4 .

\section{Yield of cell walls isolated from strains $B$ and $E-26$}

Cell walls were isolated from Escherichia coli B and E-26 grown in defined medium as well as from the same organisms grown in inducing medium. The results are shown in Table 1. When the isolation procedure involved only cell breakage and

Table 1. Effect of trypsin on the yield of cell walls from two strains of Escherichia coli

\begin{tabular}{|c|c|c|c|c|c|c|}
\hline $\begin{array}{c}\text { Expt. } \\
\text { no. }\end{array}$ & $\begin{array}{l}\text { E. coli } \\
\text { strain }\end{array}$ & $\begin{array}{l}\text { Growth } \\
\text { medium* }\end{array}$ & $\begin{array}{l}\text { Bacteria } \\
\text { dry wt. } \\
\text { (g./100 ml. } \\
\text { of culture) }\end{array}$ & $\begin{array}{l}\text { Trypsin } \\
\text { treat- } \\
\text { ment }\end{array}$ & $\begin{array}{c}\text { Cell wall } \\
\text { dry wt. } \\
\text { ( } \mathrm{mg} . / 100 \mathrm{ml} \text {. } \\
\text { of culture) }\end{array}$ & $\begin{array}{c}\text { Cell walls } \\
\text { as } \% \\
\text { dry wt. } \\
\text { of bacteria }\end{array}$ \\
\hline 1 & E-26 & IM & $0 \cdot 198$ & + & $30 \cdot 9$ & $15 \cdot 6$ \\
\hline 2 & E-26 & $\mathbf{I M}$ & $0 \cdot 189$ & - & $33 \cdot 1$ & $17 \cdot 5$ \\
\hline $\mathbf{3}$ & E-26 & DM & $0 \cdot 191$ & + or - & $32 \cdot 4$ & 16.9 \\
\hline 4 & B & IM & $0 \cdot 199$ & + & 9.0 & 4.5 \\
\hline 5 & B & IM & 0.204 & - & $4.1 \cdot 4$ & $20 \cdot 3$ \\
\hline 6 & B & DM & 0.211 & + or - & $37 \cdot 3$ & $17 \cdot 7$ \\
\hline
\end{tabular}

exhaustive washing with water the two strains yielded approximately the same amount of cell walls/g. dried bacteria (17.0-20.3\%) independent of the growth medium. However, when cell wall isolation included trypsin treatment, as suggested by Salton (1964), the yield of strain E-26 cell walls, regardless of growth medium, remained constant while that of strain $B$ walls from organisms grown in inducing medium decreased by $75 \%$. The walls of strain B grown in defined medium were resistant to trypsin. The marked decrease in strain B cell-wall yields after trypsin treatment suggested the possibility of using various enzymes as aids in characterizing the structural difference observed.

\section{Trypsin sensitivity of isolated cell walls}

The effect of trypsin on the isolated cell walls of strain B can be seen in Fig. 1 . Trypsin studies are presented only on cell walls isolated from organisms grown in 


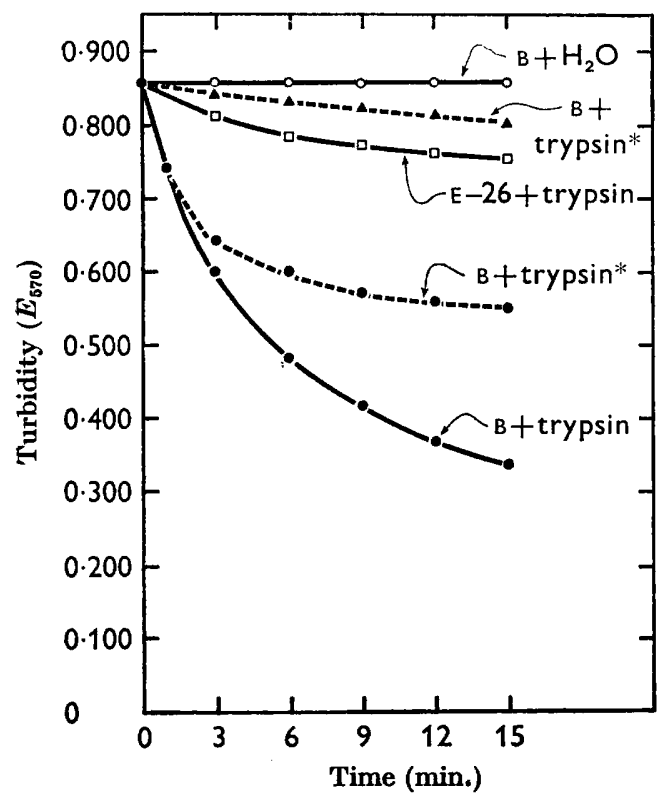

Fig. 1

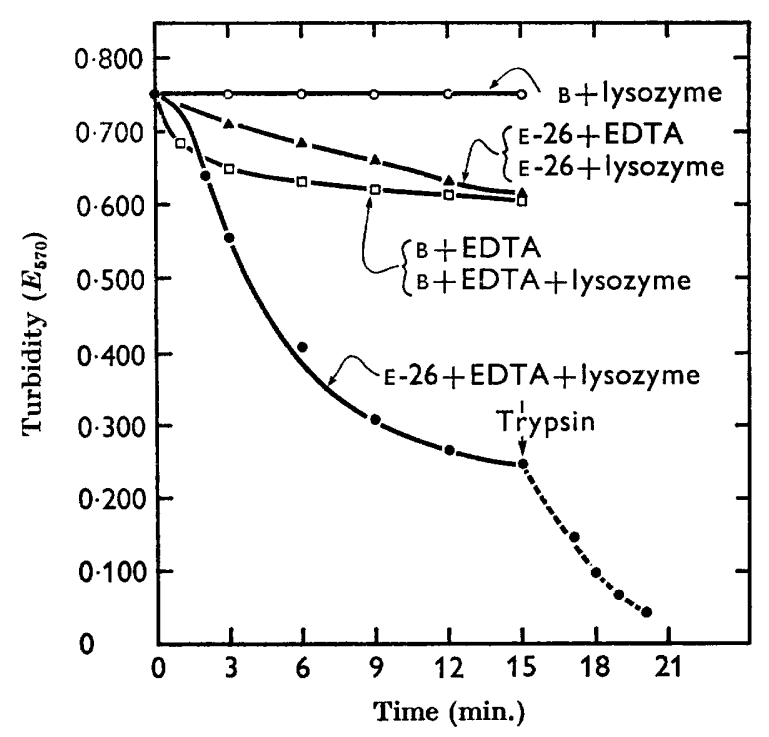

Fig. 2

Fig. 1. The effect of trypsin on isolated cell walls from $E$. coli B and E-26. Trypsin is present at $0.005 \%(\mathrm{w} / \mathrm{v})$ and $\mathrm{Ca}^{2+}$ at $1 \times 10^{-3} \mathrm{M}$ final concentration. Trypsin* indicates soy bean trypsin inhibitor added at $100 \mu \mathrm{g} . / \mathrm{ml}$. final concentration. $\Delta-. \Delta$ soy bean trypsin inhibitor added at zero time, -.- soy bean trypsin inhibitor added $1.5 \mathrm{~min}$. after trypsin addition.

Fig. 2. The effect of lysozyme on isolated cell walls from Escherichia coli B and E-26. Lysozyme final concentration is $50 \mu \mathrm{g} . / \mathrm{ml}$. and EDTA final concentration $1 \times 10^{-8} \mathrm{M}$. Trypsin is added under the same conditions as described for Fig. 1.

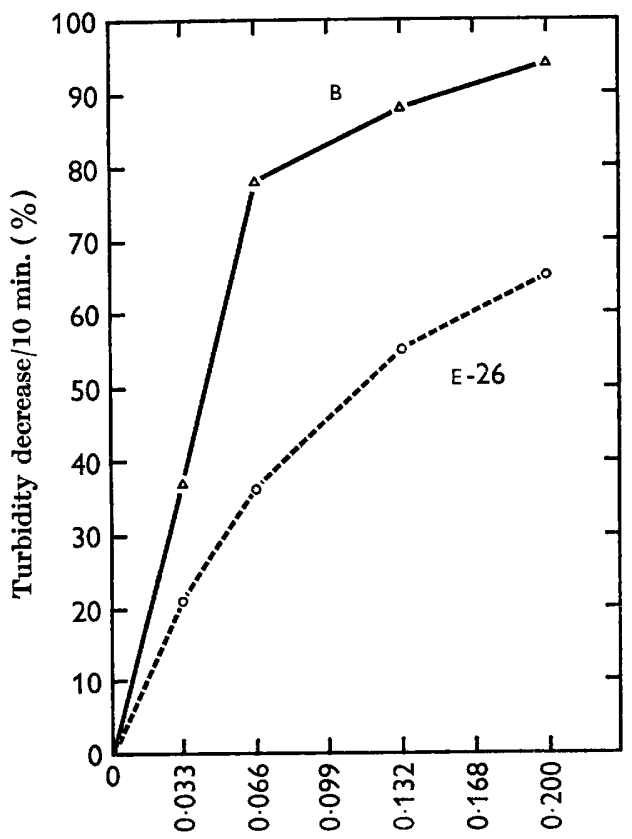

Sodium dodecyl sulphate (w/v) \%

Fig. 3. The effect of various concentrations of sodium dodecyl sulphate (SDS) on isolated cell walls of $E$. coli $\mathrm{B}$ and $\mathbf{E - 2 6}$. All SDS treatment was at pH 7·0. 
inducing medium since walls from strains B and E-26 grown in defined medium were resistant to trypsin treatment. If soy bean trypsin inhibitor was present with cell walls from strain $\mathrm{B}$, trypsin caused little turbidity change. Cell walls from strain E-26 appeared resistant to trypsin. However, it appeared that trypsin rapidly attacked cell walls from strain B. Substitution of the proteolytic enzyme pronase for trypsin gave essentially identical results. The apparent tryptic lysis of the aberrant strain B cell walls may be due to trypsin liberation of a lytic enzyme, attached to the cell walls and not removed by the washing process. This possibility, however, was rendered very unlikely by the effect of soy bean trypsin inhibitor added $1.5 \mathrm{~min}$. after trypsin addition. The inhibition of the rate and extent of lysis suggests that trypsin is the causative agent in turbidity reduction.

\section{Lysozyme sensitivity of isolated cell walls}

Lysozyme was used as an additional aid in characterizing the aberrant cell walls of strain B. Figure 2 shows that strain E-26 cell walls were sensitive to lysozyme in the presence of EDTA $\left(1 \times 10^{-3} \mathrm{M}\right)$. There was no difference in cell-wall lysozyme sensitivity when E-26 were grown in either defined medium or inducing medium. Under identical conditions, the strain B cell walls were unaffected by treatment with lysozyme and EDTA. The slight change in turbidity in the presence of EDTA alone was also noted by Repaske (1958), and has not been adequately explained. It is interesting to note in Fig. 2 that once E-26 cell walls have been attacked by lysozyme, the walls become sensitive to trypsin. An attempt to interpret this observation will be presented in the Discussion.

\section{Sensitivity of isolated cell walls to SDS dissolution}

Shafa \& Salton (1960) have shown that sodium dodecyl sulphate (SDS) at $\mathbf{0 . 2} \%$ $(\mathrm{w} / \mathrm{v})$ and $\mathrm{pH} \mathrm{7.0}$ can cause dissolution of Escherichia coli cell walls resulting in a $70 \%$ decrease of the original turbidity. The results of a similar experiment are seen in Fig. 3. Various concentrations of SDS were used against cell wall suspensions of strains E-26 and B. The walls were obtained from organisms grown in inducing medium. The results show that at all concentrations of SDS the aberrant cell walls of strain $\mathbf{B}$ are more susceptible to disaggregation than those of strain E-26. At $0.2 \%(w / v)$ SDS approximately $33 \%$ of the original turbidity of strain E-26 cell walls remained; by comparison, less than $5 \%$ of the turbidity due to strain B cell walls was demonstrable.

\section{Chemical analysis of whole bacteria and isolated cell walls}

Preliminary experiments were performed to determine growth variation in the morphologically aberrant forms in the rigid layer (as measured by hexosamine concentration), or in whole cell lipopolysaccharide (as measured by reducing sugar concentration) content. It was found that the aberrant forms had much lower total hexosamine and reducing sugar values-about one-third to one-fifth of the content in morphologically normal organisms. In order to determine if these variations were specifically located in the cell walls, chemical analysis of isolated cell walls was done. These data are presented in Table 2. Cell walls from abnormal strain B cells had a hexosamine concentration only one-third of that present in strain E-26 cell walls. Normal strain B cell walls had a hexosamine content 
similar to that of strain $\mathrm{E}-26$ walls, using either the indole $+\mathrm{HCl}$ or Elson-Morgan procedure. Reducing sugar determinations showed that the abnormal strain $B$ cell walls had one-fifth the amount of reducing substance of strain E-26 cell walls. Again, the normal strain B cell walls had reducing sugar values similar to those obtained for strain E-26 cell walls. This was true regardless of whether the bacteria were initially boiled or treated with a $0 \cdot 4 \%(w / v)$ SDS prior to cell-wall isolation in order to inhibit lytic enzyme activity. The protein determinations showed that cell walls from strain B grown in inducing medium had more protein associated with them than strain E-26 walls isolated from inducing medium grown organisms. Qualitative paper chromatography of acid-hydrolysed cell walls from each strain showed no difference in the amino acid pattern. Also, the amino acid composition of rigid layer isolated from walls showed no strain variation.

Table 2. Chemical analysis of cell walls from two strains of Escherichia coli grown in inducing medium

\begin{tabular}{|c|c|c|}
\hline \multirow[b]{2}{*}{ Component analysed } & \multicolumn{2}{|c|}{$\begin{array}{l}\% \text { dry wt. } \\
\text { cell walls }\end{array}$} \\
\hline & $\mathrm{E}-26$ & $\mathbf{B}$ \\
\hline Hexosamine (Indole-HCl method) & $\mathbf{2 \cdot 9}$ & $1 \cdot 1$ \\
\hline Hexosamine (Elson-Morgan method) & 4.5 & 1.9 \\
\hline Reducing sugars (Anthrone method) & $5 \cdot 0$ & $1 \cdot 1$ \\
\hline Protein (Lowry method) & $62 \cdot 4$ & $74 \cdot 2$ \\
\hline
\end{tabular}

Table 3. Reduced NAD oxidase activity in cell walls and supernatants from two strains of Escherichia coli grown in inducing medium

\begin{tabular}{lcr}
\multicolumn{1}{c}{ Fraction analysed } & $\mathbf{E - 2 6}$ & \multicolumn{1}{c}{$\mathbf{c}$} \\
Reduced NAD oxidase of cell walls (S.A.*) & $14 \cdot 0$ & $\mathbf{7 9 \cdot 0}$ \\
Reduced NAD oxidase of cell supernatants (S.A.*) & $.7 \cdot 2$ & $4 \cdot 5$ \\
Total units $\dagger$ in cell walls & 1,890 & 12,195 \\
Total units $\dagger$ in cell supernatants & $\mathbf{3 , 4 5 6}$ & 1,598
\end{tabular}

* Specific activity is expressed as $\mathrm{m} \mu$ moles $/ \mathrm{min} . / \mathrm{mg}$. protein.

$\dagger$ Total units of enzyme activity is expressed as $\mathrm{m} \mu$ moles $/ \mathrm{min}$./g. dry wt. of bacteria.

\section{Reduced NAD oxidase activity in isolated cell walls}

Cell wall + cell membrane complexes are isolated from Gram-negative cell-wall preparations (Salton, 1964). Studies have established that many enzymes are associated with the cell membrane (Salton, 1964) and reduced NAD+cell oxidase was chosen as a stable representative of a typical enzyme present in the cell membrane. The data in Table 3 show that aberrant strain B cell wall + membrane complexes have 5 times more of this enzyme activity than cell wall + cell membrane complexes from strain E-26. Dialysed supernatants combined with the washings from cell-wall isolaions were also assayed for the reduced NAD oxidase. The difference in the values of enzyme in the two cell-wall preparations could not be accounted for by the amount of enzyme released into the soluble fraction. The total amount of enzyme activity was $2 \cdot 6$ times higher in the strain $\mathrm{B}$ than in the E-26. The distribution showed that $88 \%$ of the reduced NAD oxidase activity was in the cell wall + cell membrane of strain B, but only $35 \%$ of the enzyme activity was associated with the cell wall + cell membrane complex of strain E-26. 


\section{DISCUSSION}

The morphological variants of Escherichia coli described here are unusual only because they are formed in response to a supposedly non-bacteriostatic environment. It has been shown that cell-wall composition, as determined by lysozyme sensitivity, can be altered by the growth medium (Litwack \& Pramer, 1956). It is possible that the inducing medium, containing a very high concentration of casein hydrolysate $(5 \%, w / v)$, may be acting in a manner similar to high concentrations of certain amino acids-notably glycine. It is well established that $3 \%(\mathrm{w} / \mathrm{v})$ glycine will induce spheroplast formation in a suitable osmotically protective medium (Jeynes, 1961). This spheroplast formation is thought to be mainly due to inhibition by glycine of the reaction in which L-alanine is added to UDP-acetylmuramic acid (Strominger \& Birge, 1965). The spheroplasts formed in such an environment are capable of propagation in serial culture, but become progressively smaller and require increasing concentrations of glycine to maintain the spheroplast form. Arguing against the possibility that the inducing medium acted here in a similar manner were the observations that (1) growth and morphological variation during propagation in serial subculture were identical to the characteristics observed in the original culture, (2) multiple factors were required for the observed morphological variation (i.e. lysine, nutrient broth and Hycase were required for branched forms and Hycase alone for filament formation), and (3) substitution of the casein hydrolysate in the inducing medium with components rich in amino acids did not give uniform induction of aberrant forms, showing that amino acid concentration was not the sole factor in causing the abnormal cell formation. The role of the lysine in the medium is quite complex. It is possible that lysine is feedback-inhibitory or represses the synthesis of diaminopimelate, thus regulating mucopeptide completion. Substitution of other amino acids (glycine or alanine), for lysine reduced branched cell formation. However, filament formation was unimpaired. The chemical analysis of the cell walls of the morphological variants showed that while the quantity of hexosamine was greatly decreased, it was still present in sufficient concentration to support the suggestion that some rigid layer is a component of the isolated cell walls. This is in agreement with the findings of Vaituzis \& Doetsch (1965) showing that aberrant filamentous and branched forms result during recovery of Salmonella typhimurium from spheroplast induction by penicillin. In other words, it is only during the recovery, or intermediate, phase (i.e. rigid layer synthesizing period) that the aberrant organisms are observed. When sufficient rigid layer has been synthesized the organisms regain their normal morphology. One interpretation presently available is that the aberrant forms of $\boldsymbol{E}$. coli в have been induced by partial inhibition of cell-wall synthesis and that these forms have only a small portion of the normal rigid layer.

This interpretation is further strengthened in these studies by the use of trypsin and lysozyme. Escherichia coli E-26 cell walls appear to be resistant to trypsin attack since the continuous rigid layer is able, by covalent or ionic bonding, to prevent the tryptic fragments from disaggregating. On the other hand, the rigid layer of strain $\mathrm{B}$ is thought to be discontinuous and therefore not capable of holding the tryptic fragments. Consequently, the walls disaggregate during trypsin treatment. Once the strain E-26 rigid layer has been made discontinuous by the action 
of lysozyme these cell-walls become highly susceptible to trypsin disaggregation. The results of detergent (SDS) dissolution of strain E-26 cell walls shows that $30 \%$ of the initial turbidity remains, supposedly due to non-solubilized intact rigid layer. However, dissolution of strain B cell walls with SDS was almost complete, increasing the possibility that the rigid layer is partially absent or in some way discontinuous. Finally, the observation that filamentous and branched forms of $E$. coli B had 5 times more reduced NAD oxidase activity associated with their cell wall + cell membrane complex than strain E-26 can be explained by the fact that strain B walls have more protein and also more enzyme. It is also possible that the two enzymes (and hence the membranes) are different and the strain B oxidase is five times more active. This can only be clarified by purification of the enzyme from both wall preparations.

This work was supported by a grant, AM 07418, from the National Institute of Arthritis and Metabolic Diseases, U.S. Public Health Service.

\section{REFERENCES}

Adler, H. I. \& Hardigree, A. A. (1964). Analysis of a gene controlling cell division and sensitivity to radiation in Escherichia coli. J. Bact. 87, 720.

Balley, J. L. (1962). Techniques in Protein Chemistry. Amsterdam: Elsevier Publishing Co.

Bartmann, K. \& Höpken, W. (1956). Zur Frage des sogenannten unvollständigen L-Zyklus. Zeutbl. Bakt. (I Orig.), 166, 30.

Bноск, T. D. (1962). Effects of magnesium ion deficiency on Escherichia coli and possible relation to the mode of action of novobiocin. J. Bact. 84, 679 .

Coggin, J. H., Jun. \& Martin, W. R. (1965). 6-Diazo-5-oxo-L-norleucine inhibition of Escherichia coli. J. Bact. 89, 1348.

Dische, Z. (1955). New color reactions for determination of sugars in polysaccharides. Meth. biochem. Analysis, 2, 313.

Dische, Z. \& Borenfreund, E. (1950). A spectrophotometric method for the microdetermination of hexosamines. J. biol. Chem. 185, 517.

Hrrs, C. H. W. (1955). Chromatography of enzymes on ion exchange resins. Meth. Enzymol. 1, 113.

Holden, J. T. \& Holman, J. (1957). Abnormal cellular morphology associated with a vitamin $\mathrm{B}_{6}$ deficiency in Lactobacillus arabinosus. J. Bact. 73, 592.

Hughes, W. H. (1953). The origin of the L-form variants in anaerobic cultures of Bacterium coli. J. gen. Microbiol. 8, 307.

Hughes, W. H. (1956). The structure and development of the induced long forms of bacteria. Symp. Soc. gen. Microbiol. 6, 341.

Jeynes, M. H. (1961). The growth and division of bacterial protoplasts. Exp. Cell Res. 24, 255.

Kitahara, K. \& Kusaka, I. (1959). Pleomorphism in bacterial cells. I. Filament formation in Lactobacillus delbrueckii and its relation to vitamin $\mathrm{B}_{12}$. J. gen. appl. Microbiol. (Tokyo), $5,78$.

Litwack, G. \& Pramer, D. (1956). Growth of Micrococcus lysodeikticus as a substrate for lysozyme. Proc. Soc. exp. Biol. Med. 91, 290.

Lowry, O. H., Rosebrough, N. J., Farr, A. L. \& Randall, R. J. (1951). Protein measurement with the Folin phenol reagent. J. biol. Chem. 193, 265.

MorA, J. \& BojaliL, L. F. (1965). Antagonism of the D-alanine reversal of D-cycloserine action by L-alanine in Mycobacterium acapulcensis. Proc. Soc. exp. Biol. Med. 119, 49.

Pontefract, R. D. \& Thatcher, F. S. (1965). A cytological study of normal and radiationresistant Escherichia coli. Can. J. Microbiol. 11, 271. 
RePaske, R. (1958). Lysis of Gram-negative organisms and the role of versene. Biochim. biophys. Acta, 30, 225.

Salton, M. R. J. (1964). The Bacterial Cell Wall. Amsterdam: Elsevier Publishing Co. Scotт, T. A. \& Melvin, E. H. (1953). Determination of dextran with anthrone. Anal. Chem. 25, 1656.

Shafa, F. \& Salton, M. R. J. (1960). Disaggregation of bacterial cell walls by anionic detergents. J. gen. Microbiol. 23, 137

Shockman, G. D., Kolb, J. J. \& Toennies, G. (1957). A high speed shaker for the disruption of cells at low temperature. Biochim. biophys. Acta, 24, 203.

Strominger, J. L. \& Birge, C. H. (1965). Nucleotide accumulation induced in Staphylococcus aureus by glycine. J. Bact. 89, 1124.

VAITUzis, Z. \& Doetsch, R. N. (1965). Flagella of Salmonella typhimurium spheroplasts. J. Bact. 89, 1586.

Weidel, W., Frank, H. \& Leutgeb, W. (1963). Autolytic enzymes as a source of error in the preparation and study of Gram-negative cell walls. J. gen. Microbiol. 30, $12 \%$.

Weinbaum, G. \& Mallette, M. F. (1959). Enzyme biosynthesis in Escherichia coli. J. gen. Physiol. 42, 1207.

Weinbaum, G. \& Fischman, D. (1965). Morphologic variation in Escherichia coli. Bact. Proc. p. 35.

Weinbaum, G. (1965). Cellular response to environment. I. Morphologic variation in Escherichia coli. J. Einstein med. Cent. 13, 176.

Winzuer, R. J. (1955). Determination of serum glycoproteins. Meth. biochem. Analysis, 2, 279.

Zobels, C. E. \& CoBet, A. B. (1964). Filament formation by Escherichia coli at increased hydrostatic pressures. J. Bact. 87, 710 .

\section{EXPLANATION OF PLATE}

Escherichia coli B grown in inducing medium showing fig. 1, filamentous, fig. 2, filamentous branched, and fig. 3 branched cells. Phase micrographs at magnification, $\times 4000$. Figure $4, E$. coli E-26 grown in inducing medium showing normal rod shapes. Phase micrograph magnification is $\times 4000$. 
Journal of General Microbiology, Vol. 42, No. 1

Plate 1
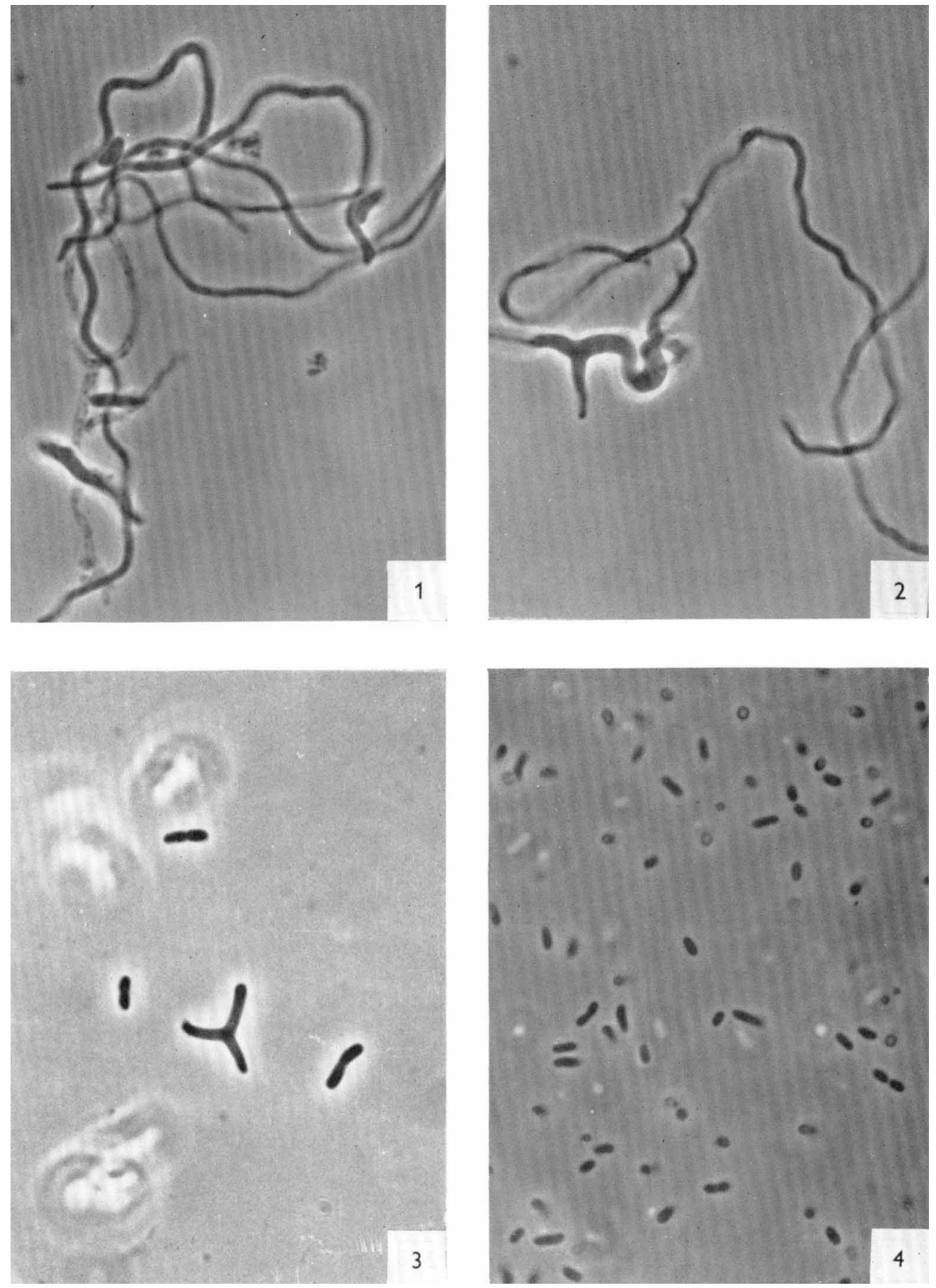

G. WEINBAUM 